\title{
Basosquamous Carcinoma - A Rare Presentation: Case Report With Review Of Literature
}

\author{
S Gole, G Gole, A Deshpande, V Satyanarayana
}

\section{Citation}

S Gole, G Gole, A Deshpande, V Satyanarayana. Basosquamous Carcinoma - A Rare Presentation: Case Report With Review Of Literature. The Internet Journal of Pathology. 2013 Volume 14 Number 1.

\begin{abstract}
Introduction:Basosquamous cell carcinoma (BSC) is a rare cutaneous neoplasm with features of both basal cell carcinoma (BCC) and squamous cell carcinoma (SCC) which has a potential for aggressive infiltration and destruction. BSC has reported incidence rate of $1-2 \%$ of all carcinomas of the skin. Here we discuss a rare presentation of BSC with review of literature.Material and methods: An elderly male presented with an ulcer over the left temporal region and history of loss of ear lobule 6 years back. Formalin fixed tissue sections were stained with hematoxylin and eosin. Histopathology revealed basosquamous carcinoma. Conclusion: Basosquamous carcinoma is a rare aggressive skin tumor with a propensity for lymph node and distant metastases. It is radioresistant and has a poor prognosis. Surgical excision with negative margins and long term follow-up are essential.
\end{abstract}

\section{INTRODUCTION}

Basosquamous cell carcinoma (BSC) is a rare cutaneous neoplasm with features of both basal cell carcinoma (BCC) and squamous cell carcinoma (SCC) which has a potential for aggressive infiltration and destruction. Initially a subject of considerable debate, BSC is now generally accepted to exist as a separate entity, with a reported incidence rate of $1-2 \%$ of all carcinomas of the skin. ${ }^{[1]}$

\section{MATERIAL AND METHODS}

A case of BSC is being discussed. Formalin fixed tissue sections were stained with hematoxylin and eosin.

\section{CASE HISTORY}

A 60-year-old male presented with an oval ulcer over the left temporal region with loss of left ear lobule 6 years back (Figure 1). 


\section{Figure 1}

Figure 1: Basosquamous carcinoma eroding the left ear lobule.

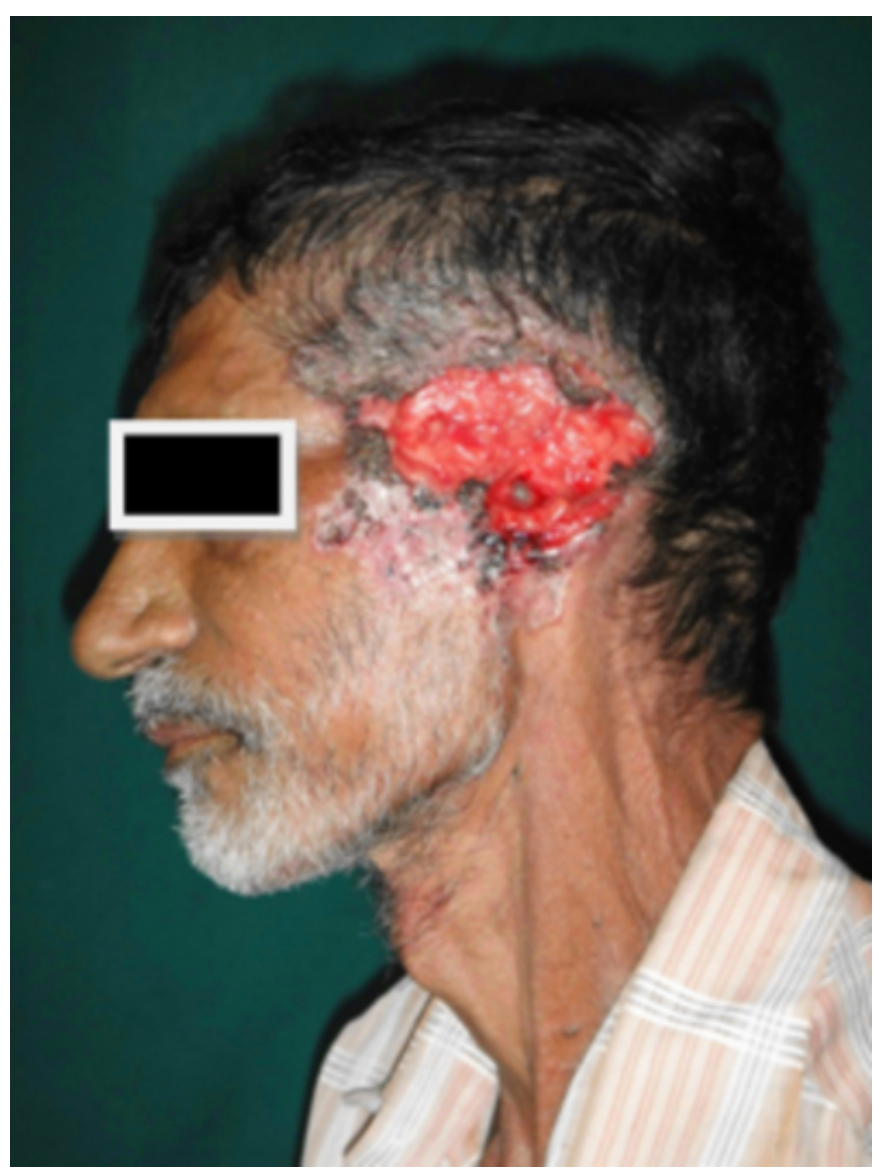

The ulcer measured $6 \times 5 \mathrm{~cm}$, with punched out edges and the base had papillary excrescences. Wedge biopsy was sent for HPE. Microscopically, tumor cell nests were seen with predominantly basaloid cells, having uniform round to oval, dark nuclei with peripheral palisading and retraction of surrounding fibrocollagenous stroma (Figure 2).

\section{Figure 2}

Figure 2: Photomicrograph [40 X] showing tumour cell nest with small dark basophilic cells and squamous cell foci along with peripheral palisading and retracted space.

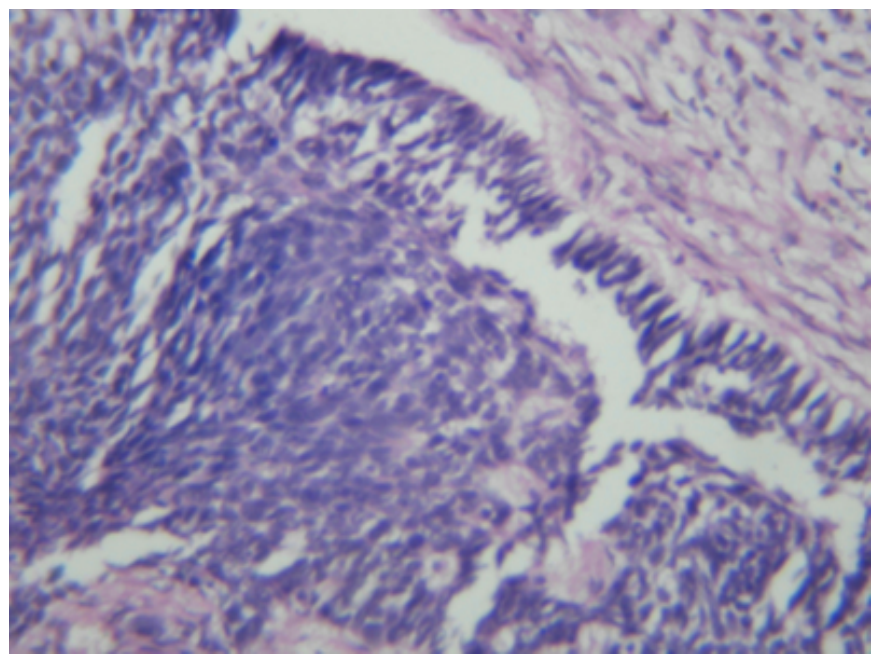

At places the cells revealed squamous differentiation with moderate to marked pleomorphism of keratinocytes. Tumour cell nests were separated by marked lymphocytic infiltrate (Figure 3). It was reported as metatypical basosquamous carcinoma.

\section{Figure 3}

Figure 3: Photomicrograph [10 X] showing tumour cell nests separated by marked lymphocytic infiltrate

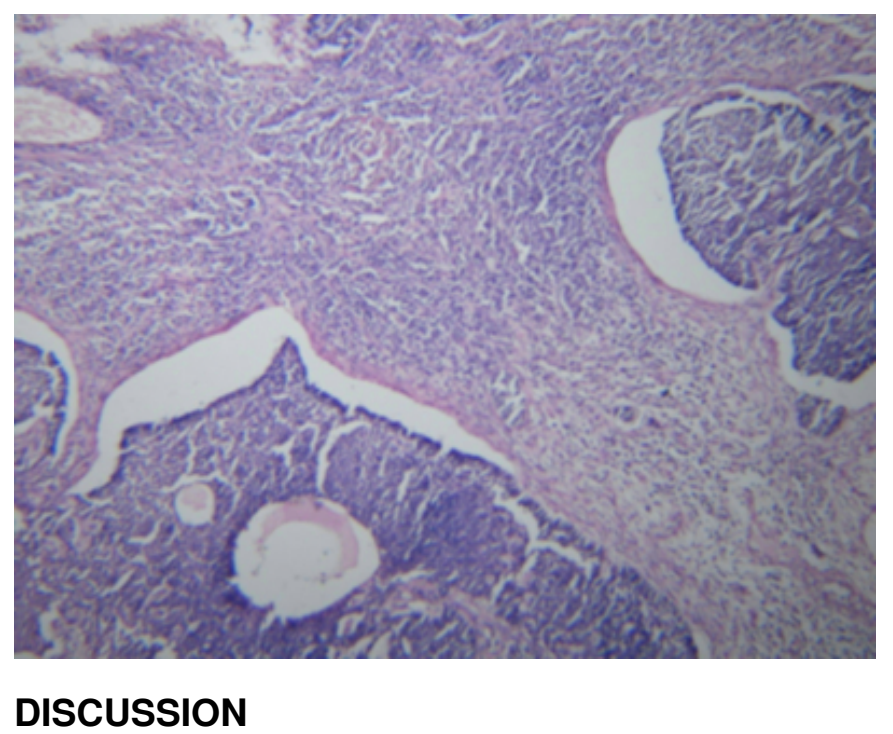

Basosquamous carcinoma (BSC) was first described in 1910 by MacCormac and later by various authors as a tumor having histologic features of both BCC \& SCC. ${ }^{[2]} \mathrm{BSC}$ is a rare tumor with an incidence of less than $2 \%{ }^{[3]}$ Whether BSC exists as a distinct entity or merely represents a collision of two neoplasms has been a matter of considerable 
debate. ${ }^{[4]}$ Most authors consider it as a variant of BCC, which differentiates into SCC. While some authors ${ }^{[4]}$ recommend the exclusion of a collision tumor and a keratinizing $\mathrm{BCC}$ before making a diagnosis of BSC, others ${ }^{[5]}$ list 3 histopathological variants: collision tumors, tumors showing distinct areas of basal and squamous differentiation, and metatypical carcinomas. Burston and Clay, defined the BSC as BCC differentiating into SCC ${ }^{[6]}$ It is now believed that $\mathrm{BCC}$ cells, being pluripotential cells, differentiate into the more aggressive squamous cells. ${ }^{[7]}$ In our case keratinizing BCC was ruled out as there was absence of any abrupt keratinisation at the centre of the $\mathrm{BCC}$ tumor nodule. In case of combined or collision tumors, BCC abuts to an adjacently arising $\mathrm{SCC},{ }^{[8]}$ which was not so in our case.

On the basis of immunohistochemistry, the term BSC can be applied to tumors resembling BCC that have areas of squamoid differentiation and show positive staining for Ber EP4 ((Epithelial antigen: Clone Ber EP4) with negative staining for EMA (Epithelial membrane antigen: Clone E29). ${ }^{[9]}$ BSC shows areas of definitive BCC (Ber EP4+) and SCC (cytokeratin AE1/AE3+) with a transition zone of diminished staining. ${ }^{[10]}$

BSCs are more common in men; usually presenting in the fifth to eighth decades of life. ${ }^{[3]}$ Although few cases are reported even in the second decade. In the series reported by Borel, ${ }^{[11]} 97 \%$ of the tumors were located on the head and neck. Face and ears being the commonest sites. ${ }^{[7]}$ However, BSCs have also presented as ulceroproliferative lesions in the vulva. ${ }^{[12]}$ Few other authors found a head and neck location in $82 \%^{[1]}$ and $96 \%{ }^{[13]}$ of patients. Our case was also situated in head region with relation to ear. The clinical morphology of BSCs has ranged from flat, rusty red colored tumors with clinically indistinct borders to ulcerative cutaneous neoplastic growths causing complete destruction of underlying soft tissue and bone, as in our case in which there was loss of the entire ear lobule. BSC is more locally invasive and more likely to recur and metastasize than other forms of BCC [Table 1]. ${ }^{[13]}$

Table 1: Aggressiveness of basosquamous cell carcinoma
Figure 4

\begin{tabular}{|ccc|}
\hline & Local recurrence rate (\%) & $\begin{array}{c}\text { Rate of occurrence } \\
\text { of distant metastases (\%) }\end{array}$ \\
\hline & & \\
\hline BSC & 45.7 & $4-8.6$ \\
\hline BCC & 24.2 & 0.09 \\
\hline SCC & 21.9 & 7.9 \\
\hline
\end{tabular}

Metastases of BSC are known to occur many years after identification of the primary tumor. ${ }^{[14]}$ These tumors are radioresistant. Hence such patients should undergo regular follow-up as long as possible. Johnson et al has described BSC as a wolf in sheep's clothing. ${ }^{[15]}$

A male gender, large size ( $>20 \mathrm{~mm})$, positive surgical resection margins and lymphatic or perineural invasion are indicators for the aggressiveness of basosquamous carcinoma. ${ }^{[1]}$ The 5-year survival rate is estimated to be $17.5 \% .^{[16]}$

MacCormac (1910) stated: This group includes a few growths where great difficulty is found in determining whether the neoplasm should be classified as a rodent ulcer or as a Malpighian cancer. ${ }^{[1]}$ Where squamous cell differentiation has occurred in a BCC, unless the squamous cells themselves show malignant features, they are unlikely to influence the prognosis of the tumor, and thus any diagnosis which draws attention to them would be therapeutically valueless. ${ }^{[6]}$ This view has been previously stated by Broders (1925), who pointed out that cells showing signs of keratinisation are not capable of reproduction and that such cells are not active cancer cells. They cannot therefore of themselves be regarded as evidence of increased malignancy in any tumor in which they occur. ${ }^{[6]}$ Considering the histopathlogical description of BSC, it shows nests and strands of cells that mature into larger, paler and round cells. Peripheral palisading, if any, is less developed than in other types of BCC with minimal stromal retraction. ${ }^{[17]}$ Prominent stroma, prominent mitotic activity, and many apoptotic cells may be present. BCC is seen differentiating into SCC. It also consists of squamoid cells and intermediate cells.

\section{CONCLUSION}

Basosquamous cell carcinoma (BSC) is a rare cutaneous neoplasm with features of both basal (BCC) and squamous cell carcinoma (SCC) which has a potential for aggressive infiltration and destruction. BSC has biological aggressiveness intermediate between basal cell and squamous cell carcinomas. These tumors have been rightly described as a wolf in sheep's clothing. Surgical excision 
with negative margins and long term follow-up are essential.

\section{References}

1. Martin RC 2nd, Edwards MJ, Cawte TG, Sewell CL, McMasters KM. Basosquamous carcinoma: analysis of prognostic factors influencing recurrence. Cancer. 2000; 88:1365-1369.

2. MacCormac H. The relation rodent ulcer to squamous cell carcinoma of the skin. Arch Middlesex Hosp 1910; 19:172-83.

3. Igal Leibovitch, Shyamala C. Huilgoil, Dinesh Selva, Shawn Richards, Robert Paver. Basosquamous carcinoma: Treatment with Moh's Micrographic Surgery. Cancer July 1, 2005; Volume 104 / Number 1; 170-175.

4. Maloney ML. What is basosquamous carcinoma? Dermatol Surg 2000; 26:505-6.

5. Bianchi L, Bernardi G, Orlandi A, Chimenti S.

Basosquamous cell carcinoma with massive cranial osteolysis. Clin Exp Dermatol 2003; 2:96-7.

6 . Burston J, Clay RD. The problems of histological diagnosis in basosquamous cell carcinoma of the skin. J Clin Path.1959; 12:73-78.

7. Lopes de Faria J, Nunes PH. Basosquamous cell carcinoma of the skin with metastases. Histopathology. 1988; 12:85-94.

8. Nitin Ranjan, Satyendra K Singh, Sayeedul H Arif. Basosquamous carcinoma in an Indian patient with occulocutaneous albinism. Indian J Dermatol 54;
Supplement, January-March 2009; S63-65.

9. Beer TW, Shepherd P, Theaker JM. Ber EP4 and epithelial membrane antigen aid distinction of basal cell, squamous cell and basosquamous carcinoma of the skin. Histopathology 2000; 37:218-23.

10. Jones MS, Helm KF, Maloney ME. The immunohistochemical characteristics of the basosquamous cell carcinoma. Dermatol Surg 1997; 23:181-4.

11. Borel DM. Cutaneous basosquamous carcinoma. Arch Pathol Lab Med. 1973; 95:293-297.

12. Yesudian PD, Krishnan SG, Jayaraman M, Janaki VR, Yesudian P. Basisquamous carcinoma. Indian J Dermatol 1997; 42:123-4.

13. Bowman PH, Ratz JL, Knoepp TG, Barnes CJ, Finley

EM. Basosquamous carcinoma. Dermatol Surg . 2003; 29:830-832.

14. Farmer ER, Helwig EB. Metastatic basal cell carcinoma: A clinicopathologic study of seventeen cases. Cancer. 1980; 46:748-57.

15. Johnson BF, Moore PJ, Goepel JR, Slater DN.

Basosquamous carcinoma, a wolf in sheep's clothing?

Report of three cases. Post grad Med J. 1989; Oct; 65(768):750-1.

16. Akedniz n, Calka O, Metin A, Yuca K, Ozen S. A destructive ulcer. Clin Exp Dermatol. 2005; 30:731-2. 17. Lopes de Faria J. Basal cell carcinoma of the skin with areas of squamous cell carcinoma: a basosquamous cell carcinoma? J Clin Pathol. 1985; 38:1273-1277. 


\title{
Author Information
}

Sheetal G. Gole

Assistant Professor of Pathology, Department of Pathology and General Surgery, Kamineni Institute of Medical Sciences

\section{Gautam N. Gole}

Associate Professor of General Surgery, Department of Pathology and General Surgery, Kamineni Institute of Medical Sciences

\author{
Ashok Kumar Deshpande \\ Associate Professor of Pathology, Department of Pathology and General Surgery, Kamineni Institute of Medical Sciences \\ V. Satyanarayana \\ Professor of Pathology, Department of Pathology and General Surgery, Kamineni Institute of Medical Sciences
}

